\title{
Critical-Point Yield Model to Estimate Yield Damage Caused by Cercospora zea-maydis in Corn
}

\author{
Erlei M. Reis ${ }^{1}$, Jones A.P. Santos ${ }^{2}$ \& Marta Maria C. Blum ${ }^{3}$
}

\author{
${ }_{1}^{1}$ Faculdade de Agronomia e Medicina Veterinária, Universidade de Passo Fundo, Cx. Postal 611, CEP 99001-970, \\ Passo Fundo, RS, Brasil, email: erleireis@tpo.com.br; ²Estação Experimental Syngenta Seeds, Cx. Postal 585, CEP 38400-974, \\ Uberlândia, MG, Brasil; ${ }^{3}$ Universidade Regional Integrada do Alto Uruguai e Missões, CEP 99001-970, Erechim, RS, Brasil
}

Author for correspondence: Erlei Melo Reis

REIS, E.M., SANTOS, J.A.P. \& BLUM, M.M.C. Critical-Point Yield Model to Estimate Yield Damage Caused by Cercospora zea-maydis in Corn. Fitopatologia Brasileira 32:110-113. 2007.

\begin{abstract}
A model to estimate damage caused by gray leaf spot of corn (Cercospora zea-maydis) was developed from experimental field data gathered during the summer seasons of 2000/01 and during the second crop season [Januaryseedtime] of 2001, in the southwest of Goiás state. Three corn hybrids were grown over two seasons and on two sites, resulting in 12 experimental plots. A disease intensity gradient (lesions per leaf) was generated through application, three times over the season, of five different doses of the fungicide propiconazol. From tasseling onward, disease intensity on the ear leaf (El), and $\mathrm{El}-1, \mathrm{El}-2, \mathrm{El}+1$, and $\mathrm{El}+2$, was evaluated weekly. A manual harvest at the physiological ripening stage was followed by grain drying and cleaning. Finally, grain yield in kg.ha-1 was estimated. Regression analysis, performed between grain yield and all combinations of the number of lesions on each leaf type, generated thirty linear equations representing the damage function. To estimate losses caused by different disease intensities at different corn growth stages, these models should first be validated. Damage coefficients may be used in determining the economic damage threshold.
\end{abstract}

Additional keywords: gray leaf spot, Zea mays, losses.

\begin{abstract}
RESUMO
Modelo de ponto crítico para estimar os danos causados por Cercospora zea-maydis em milho

Desenvolveu-se um modelo para estimar os danos causados pela cercosporiose (Cercospora zea-maydis) na cultura do milho, com base em dados experimentais de campo, coletados nas safras de verão nos anos 2000/01 e na safrinha de 2001, no sudoeste goiano. Três cultivares de milho híbrido foram semeados em dois locais perfazendo um total de 12 experimentos. O gradiente da intensidade da doença, avaliada em função do número de lesões por folha, foi gerado pela aplicação de cinco doses em três épocas. A intensidade da doença foi avaliada, semanalmente, em cinco folhas, a partir do embonecamento: folha da espiga ( $\mathrm{Fe}), \mathrm{Fe}-1, \mathrm{Fe}-2, \mathrm{Fe}+1$ e $\mathrm{Fe}+2$. A colheita foi realizada na maturação fisiológica e o rendimento de grãos expresso em $\mathrm{kg}_{\text {.ha }}{ }^{-1}$. As análises de regressão entre o rendimento de grãos e o número de lesões nas cinco folhas foram realizadas para todas as combinações obtidas e geraram 30 equações lineares da função de dano. Para estimativas de danos causados por diferente intensidade da doença, em diferentes estádios de desenvolvimento fenológico, esses modelos devem, antes de tudo, serem validados. Os valores dos coeficientes de dano podem potencialmente serem utilizados no cálculo do limiar de dano econômico.
\end{abstract}

Palavras-chave adicionais: mancha foliar cinzenta, Zea mays, danos.

\section{INTRODUCTION}

Covering an area of $1.4 \times 10^{7}$ ha, with a mean yield of 3.0 tha $^{-1}$ and national production of 40 million tons in 2001, corn (Zea mays L.) is one of Brazil's most important crops (Brandalize, 2001). Several diseases threaten corn production in Brazil, particularly those related to seed germination, seedling emergence, root rots, stem rots, ear rots, rusts, smuts, along with leaf blights and spots (Reis et al., 2004). Of the latter, the principal ones reported in Brazil are of fungal origin, namely Northern corn leaf blight [Exserohilum turcicum (Pass.) K.J. Leonard \& Suggs], Southern corn leaf blight [Bipolaris maydis (Y. Nisik. \& C. Miyake) Shoemaker], phaeosphaeria leaf spot [Phaeosphaeria maydis (Henn.) Rane, Payak \& Renfro], diplodia leaf spot (Diplodia macrospora Earle), and gray leaf spot (GLS; Cercospora zeae maydis Tehon \& E.Y. Daniels). First noted in Brazil (Campinas county, São Paulo state) by Viégas and Krug in 1934 (Viégas, 1945), the latter has rarely been recorded since, and did not reach epidemic proportions at the time. However, in the southwestern regions of Goiás state, a devastating reemergence of GLS occurred, destroying the entire healthy leaf area of the second corn crop in 2000 and, in a short period of time, killing the plants altogether. A similar epidemic resurgence of GLS in the United States was attributed to monoculture and no-till crop management practices (Laterell \& Rossi, 1983; Ward et al., 1999; Fancelli, 2001). The resurgence of GLS in southwestern Goiás state occurred after more than five seasons of such crop management practices, and was estimated to have affected 
roughly 35,000 ha of susceptible cultivars. Untreated fields, and those having received an emergency fungicide application, yielded about $3.2 \mathrm{t} \mathrm{ha}^{-1}$ and $5.35 \mathrm{t} \mathrm{ha}^{-1}$, respectively (J.A.P. dos Santos personal communication). Yield losses occurred because foliar diseases remove the photosynthetic leaf area, reducing both the net amount of radiation intercepted and the translocation of photosynthates to the developing ear (Johnson, 1987). Losses in the affected region represented about US\$ 8,000,000.

In the case of plant disease epidemics, damage quantification should be a first priority; however, few reliable studies have quantified the effects of disease on corn grain yield. A number of models have been used to estimate damage caused by plant diseases. The critical-point type model is particularly useful when one can identify a specific plant growth stage at which disease intensity is closely correlated with the future damage (Bergamin Filho \& Amorim, 1996). Thus, in practice, a simple model may be applied to estimate the damage caused to the host by a specific disease in function of the host's phenologic stage and disease intensity.

In this study, we sought to quantify the deleterious effects of GLS infestation on corn yield, by generating equations which, when implemented in a critical-point yield model, would allow a prediction of impending damage as a function of different disease intensities at different host growth stages for three corn cultivars. The model-generated damage coefficient could also be used to determine the economic damage threshold.

\section{MATERIALS AND METHODS}

Experiments were conducted at three sites in Montevidiu, county in Goiás state. Corn hybrids 'Avant, 'Exceller' and 'Fort' were tested in the 2000 and 2001 summer growing seasons and in the second corn season of 2001, totaling 12 experiments.

For damage quantification it was necessary to generate a GLS infection intensity gradient. This was accomplished through the application of propiconazol [1-[[2-(2,4-dichlorophenyl)-4propyl-1,3-dioxolan-2-yl]methyl]-1H-1,2,4-triazole] fungicide at different dosages $\left(0,100,200,300,400\right.$, or $\left.800 \mathrm{~mL}^{-h^{-1}}\right)$ combined with different numbers of applications (1, 2, or 3), in a randomized complete block design, resulting in 18 thricereplicated treatments (54 individual plots) per hybrid $\times$ season (Sah \& MacKenzie, 1987). Individual experimental units were composed of four $5.0 \mathrm{~m}$-long rows spaced $0.8 \mathrm{~m}$ apart with the two lateral rows as borders. Spraying was done with a knapsack atomizer with $\mathrm{CO}_{2}$-generated pressure, a $2.0 \mathrm{~m}$-wide boom, and a volume delivered of 200 L.ha $^{-1}$

At different corn growth stages (tasseling, grain filling, and grain dough), the number of GLS lesions was counted on five leaves of five randomly chosen plants per plot. The five 'reference' leaves included the ear leaf (El), and the two immediately below and above it $(\mathrm{El}-1 ; \mathrm{El}-2 ; \mathrm{El}+1$ and $\mathrm{El}$ +2 , respectively).

At physiological maturity ears from plants of the central two rows were harvested manually, shucked, the cobs immediately dried, threshed, the grain cleaned, and kernels weighed. Grain yield was expressed in kg.ha-1 .

Regression analyses were performed between grain yield as dependent variable and GLS intensity as independent variable for cultivars, sites and growth stages. Equations were expressed on the basis of grain yield (Y) normalized to 1,000 kg.ha ${ }^{-1}$ in the form $\mathrm{Y}=1000-a(\mathrm{NL})$. Where $a$ is the damage coefficient (kg.leaf.ha ${ }^{-1}$.lesion ${ }^{-1}$; hereafter units not indicated), $\mathrm{Y}$ is the grain yield normalized to $1,000 \mathrm{~kg}^{-1} \mathrm{ha}^{-1}$, and NL is the GLS intensity (lesions.leaf ${ }^{-1}$ ). Equations represent the criticalpoint model as sought in this work.

\section{RESULTS AND DISCUSSION}

Determination coefficients for linear regression relationships between 'Avant' grain yield and lesion number varied from 0.66 to 0.97 for normal season in 2000 and 2001 (all relationships $p \leq 0.05$ ) (Table 1). Coefficients for the second season in 2001, sampled at the grain dough stage, ranged from 0.90 to 0.99 for cultivars 'Avant' and 'Fort' (all relationships $p \leq$ 0.005 ) (Table 2), but only from 0.40 to 0.68 for 'Exceller', with relationships for its $\mathrm{El}+1$ and $\mathrm{El}+2$ leaves barely significant $(0.04<p \leq 0.05)$, and those for $\mathrm{El}, \mathrm{El}-1$, and $\mathrm{El}-2$ nonsignificant $(p>0.05)$ (Table 2). This indicates that, in general, grain yield correlated well with the number of lesions per leaf.

The damage coefficient, $a$, representing by how many kilograms one foliar lesion reduces normalized grain yield, varied in function of the leaf position and phenologic stages of the corn crop at sampling: at the tasseling stage, $3.65<a<4.77$ (mean across leaves $=4.49$ ), at early grain filling $12.66<a<$ 26.80 (mean across leaves $=15.33$ ); and at the dough stage 1.39 $<a<2.12$ (mean across leaves $=1.74$ ) $($ Table 1 ).

Based on these relationships, for a farm with an estimated yield of 10,000 kg.ha-1, growing a cultivar with a GLS susceptibility similar to that of 'Avant,' each (mean of five reference leaves) lesion occurring at the early grain filling stage would have a damage potential of $153.3 \mathrm{~kg} \cdot \mathrm{ha}^{-1}$. Nevertheless, one needs to know a farm's yield potential to convert from the $1,000 \mathrm{~kg}$ normalized yield to the actual yield of the field for which one wishes to determine the damage.

At the dough stage, the 5-leaf-mean $a$ values were 1.13, 0.81 and 0.79 for cultivars 'Avant,' 'Exceller,' and 'Fort,' respectively (Table 2), values much lower than those obtained in the normal season experiments. So far, we do not have a clear explanation for such differences; however, one should keep in mind that yield potential in the experiment carried out over the normal season was 9,852 kg.ha-1 and over the second season $5,910 \mathrm{~kg} \mathrm{ha}^{-1}$. As the values were normalized to $1,000 \mathrm{~kg}$.ha${ }^{1}$, differences in $a$ values cannot be related to the cultivar's potential yield.

The $a$ values may be used to calculate the economic damage threshold (EDT), using Munford \& Norton's (1986) equation. The EDT may be useful in making decisions about whether to use chemical control for GLS with above-ground- 
TABLE 1 - Linear regression equations relating corn grain yield (Y), normalized to $1,000 \mathrm{~kg} \cdot \mathrm{ha}^{-1}$ to the number of lesions (NL) of gray leaf spot on five reference leaves, at different phenological stages, showing the coefficient of determination $\left(\mathrm{R}^{2}\right)$ and level of significance (p). Cultivar Avant. Montevidiu, Goiás state, Brazil, 2000/2001 season

\begin{tabular}{lrrr}
\hline \hline $\begin{array}{l}\text { Leaves } \\
\text { Phenological stage }\end{array}$ & Equations & $\mathbf{R}^{2}$ & $\mathbf{p}$ \\
\hline & $\mathrm{Y}=1,000_{-} a \mathrm{NL}$ &
\end{tabular}

Tasseling :

$\begin{array}{llll}\text { EI }+2^{*} & Y=1,000-4.77 \mathrm{NL} & 0.83 & 0.011 \\ \mathrm{EI}+1 & \mathrm{Y}=1,000-4.74 \mathrm{NL} & 0.82 & 0.016 \\ \mathrm{EI} & \mathrm{Y}=1,000-3.81 \mathrm{NL} & 0.81 & 0.015 \\ \mathrm{EI}-1 & \mathrm{Y}=1,000-3.66 \mathrm{NL} & 0.66 & 0.049 \\ \text { EI }-2 & \mathrm{Y}=1,000-3.65 \mathrm{NL} & 0.86 & 0.008 \\ \text { Mean } & Y=1,000-4.49 \mathrm{NL} & 0.83 & 0.012\end{array}$

Grain filling :

\begin{tabular}{llll} 
EI +2 & $Y=1,000-26.80 \mathrm{NL}$ & 0.92 & $2.24 \times 10^{-3}$ \\
EI+1 & $Y=1,000-15.18 \mathrm{NL}$ & 0.96 & $0.72 \times 10^{-3}$ \\
EI & $Y=1,000-12.66 \mathrm{NL}$ & 0.96 & $0.65 \times 10^{-3}$ \\
El -1 & $Y=1,000-14.15 \mathrm{NL}$ & 0.94 & $1.22 \times 10^{-3}$ \\
El -2 & $Y=1,000-13.38 \mathrm{NL}$ & 0.94 & $1.24 \times 10^{-3}$ \\
Mean & $Y=1,000-15.33 \mathrm{NL}$ & 0.96 & $0.66 \times 10^{-3}$ \\
& & & \\
Grain dough: & & & \\
El +2 & $Y=1,000-2.12 \mathrm{NL}$ & 0.96 & $4.72 \times 10^{-4}$ \\
EI +1 & $Y=1,000-1.90 \mathrm{NL}$ & 0.96 & $6.66 \times 10^{-4}$ \\
El & $Y=1,000-1.83 \mathrm{NL}$ & 0.97 & $4.48 \times 10^{-4}$ \\
El -1 & $Y=1,000-1.61 \mathrm{NL}$ & 0.97 & $3.49 \times 10^{-4}$ \\
El -2 & $Y=1,000-1.39 \mathrm{NL}$ & 0.90 & $4.81 \times 10^{-4}$ \\
& & & \\
Mean & $Y=1,000-1.74 \mathrm{NL}$ & 0.96 & $4.81 \times 10^{-4}$ \\
\hline
\end{tabular}

(*) El = ear leaf; $\mathrm{El}+2$ = second leaf above $\mathrm{El} ; \mathrm{El}+1$ = first leaf above $\mathrm{El} ; \mathrm{El}-1$ = first leaf below El; and El -2 = second leaf below El.

applied fungicides. An example of such an EDT calculation may be found in a study by Reis \& Casa (2004).

The relationship between GLS severity and yield has been quantified by Nutter \& Jenco (1992). Disease severity, assessed on the middle third of the plant (leaves 6 to 10) at growth stage 7.0 (late dough stage), explained up to $90 \%$ of the variation in yield. For each $1 \%$ increase in disease severity at growth stage 7.0, yield was reduced by $47.6 \mathrm{~kg} \cdot \mathrm{ha}^{-1}$ in a susceptible maize hybrid and by $35.7 \mathrm{~kg}^{-\mathrm{ha}^{-1}}$ in a moderately tolerant hybrid. Our data cannot be directly compared with Nutter \& Jenco's, since we have no information correlating severity with number of lesions/leaf. The pathometric method
TABLE 2 - Linear regression equations relating corn grain yield (Y), transformed to $1,000 \mathrm{~kg} \cdot \mathrm{ha}^{-1}$, to the number of lesions (NL) of gray leaf spot at the grain dough stage, on five reference leaves, showing the coefficient of determination $\left(\mathrm{R}^{2}\right)$ and level of significance (p) in three corn cultivars. Montevidiu, Goiás state, Brazil, 2001 second-season crop

\begin{tabular}{|c|c|c|c|}
\hline Cultivar & Equation & $\mathbf{R}^{2}$ & $\mathbf{p}$ \\
\hline & $000-a$ & & \\
\hline
\end{tabular}

'Avant'

$\begin{array}{llll}\text { El }+2^{*} & Y=1,000-1.07 \mathrm{NL} & 0.97 & 4,31 \times 10^{-4} \\ \mathrm{EI}+1 & \mathrm{Y}=1,000-1.04 \mathrm{NL} & 0.97 & 2.56 \times 10^{-4} \\ \mathrm{EI} & \mathrm{Y}=1,000-1.08 \mathrm{NL} & 0.99 & 0.56 \times 10^{-4} \\ \text { El- } 1 & \mathrm{Y}=1,000-1.13 \mathrm{NL} & 0.96 & 5.77 \times 10^{-4} \\ \text { EI- 2 } & \mathrm{Y}=1,000-1.29 \mathrm{NL} & 0.96 & 5.35 \times 10^{-4} \\ \text { Mean } & \mathrm{Y}=1,000-1.13 \mathrm{NL} & 0.99 & 0.244 \times 10^{-4}\end{array}$

'Exceller'

$\begin{array}{llll}\text { EI }+2 & Y=1,000-0.80 \mathrm{NL} & 0.68 & 0.042 \\ \mathrm{EI}+1 & \mathrm{Y}=1,000-0.80 \mathrm{NL} & 0.66 & 0.049 \\ \mathrm{EI} & \mathrm{Y}=1,000-0.74 \mathrm{NL} & 0.52 & 0.105 \\ \mathrm{EI}-1 & \mathrm{Y}=1,000-0.87 \mathrm{NL} & 0.63 & 0.058 \\ \text { EI }-2 & \mathrm{Y}=1,000-0.69 \mathrm{NL} & 0.40 & 0.179 \\ \text { Mean } & Y=1,000-0.81 \mathrm{NL} & 0.60 & 0.070\end{array}$

'Fort'

\begin{tabular}{llll} 
EI +2 & $Y=1,000-0.94 \mathrm{NL}$ & 0.90 & $3.97 \times 10^{-3}$ \\
$\mathrm{EI}+1$ & $\mathrm{Y}=1,000-0.81 \mathrm{NL}$ & 0.97 & $2.73 \times 10^{-3}$ \\
EI & $Y=1,000-0.73 \mathrm{NL}$ & 0.94 & $1.24 \times 10^{-3}$ \\
EI - 1 & $Y=1,000-0.72 \mathrm{NL}$ & 0.96 & $0.60 \times 10^{-3}$ \\
EI - 2 & $Y=1,000-0.74 \mathrm{NL}$ & 0.91 & $2.81 \times 10^{-3}$ \\
Mean & $Y=1,000-0.79 \mathrm{NL}$ & 0.94 & $1.25 \times 10^{-3}$ \\
\hline
\end{tabular}

(*) $\mathrm{El}=$ ear leaf; $\mathrm{El}+2$ = second leaf above $\mathrm{El} ; \mathrm{El}+1$ = first leaf above $\mathrm{El} ; \mathrm{El}-1$ = first leaf below $\mathrm{El}$; and $\mathrm{El}-2=$ second leaf below El.

employed, number of lesions per leaf, demands more time in disease quantification than does simple severity, but it is more objective than the latter as used by Nutter \& Jenco (1992).

The methodology used in the present work may be followed to obtain the damage function for other corn leaf blights, such as Southern corn blight and Northern corn blight, diplodia leaf blight, phaeosphaeria and for corn rusts.

Averaged across five reference leaves 'Avant,' 'Fort,' and 'Exceller' had, respectively, 110.2, 75.2 and 72.0 GLSinduced foliar lesions per leaf (Table 3). These values may reflect cultivar susceptibility to GLS and may suggest that the resistance/tolerance character is related to host penetration mechanism. The greatest lesion number was counted on the older, lower leaves (El - 2: 109.3 lesions/leaf) and decreased progressively toward the upper leaves (El - 1 - 96.5, El - 88,9, 
$\mathrm{El}+1-74.2$ and $\mathrm{El}+2-60.2$ lesions/leaf). The maximum number of lesions counted per leaf was 141.8 on El - 2, cultivar 'Avant' (Table 3). Above this intensity of infection, lesion coalescence makes counting difficult.

TABLE 3 - Number of lesions of Cercospora zea-maydis on reference leaves, in three corn cultivars, showing means of three sites. Rio Verde, Goiás state, Brazil

\begin{tabular}{|c|c|c|c|c|}
\hline \multicolumn{4}{|c|}{ Cultivars } & \multirow[b]{2}{*}{ Mean } \\
\hline Leaves & 'Avant' & 'Fort' & 'Exceller' & \\
\hline $\mathrm{E} 1-2 *$ & 141.8 & 94.0 & 92.1 & 109.3 \\
\hline El -1 & 121.5 & 84.1 & 83.9 & 96.5 \\
\hline $\mathrm{El}$ & 111.0 & 77.6 & 78.0 & 88.9 \\
\hline $\mathrm{El}+1$ & 95.1 & 67.1 & 60.3 & 74.2 \\
\hline $\mathrm{El}+2$ & 81.8 & 53.0 & 45.9 & 60.2 \\
\hline Mean & 110.2 & 75.2 & 72.0 & \\
\hline
\end{tabular}

(*) El = ear leaf; $\mathrm{El}+2$ = second leaf above El; El + 1 = first leaf above El; $\mathrm{El}-1$ = first leaf below $\mathrm{El}$; and $\mathrm{El}-2=$ second leaf below El.

GLS clearly has the potential to cause great damage to the corn crop. The assessment criterion of number of lesions per leaf, in being quantitative rather than subjective, is more reliable than severity in estimating damage. The equations relating lesions per leaf to grain yield can be used to estimate the damage caused by GLS in cultivars with a similar susceptibility/ resistance to those tested in the present work.

\section{ACKNOWLEDGMENTS}

We wish to thank Ademir Capelaro from Syngenta Seeds for financial and technical support of this investigation.

\section{REFERENCES}

BERGAMIN FILHO, A. \& AMORIM, L. Doenças de plantas tropicais: epidemiologia e controle econômico. São Paulo SP. Editoria Ceres. 1996.

BRANDALIZE, V. Nova realidade do mercado de milho. In: Fancelli, A.L. \& Dourado Neto, D. (Eds.) Milho: Tecnologia e Produtividade. Piracicaba SP. ESALQ-LPV 2001. pp. 1-9.

FANCELLI, L.A. Cercosporiose do milho: ocorrência e controle. In: Fancelli, L.A. \& Dourado Neto, D. (Eds.) Milho: Tecnologia e produtividade. Piracicaba SP. ESALQ-LPV. 2001. pp. 96-113.

JOHNSON, K.B. Defoliation, disease, and growth: A reply. Phytopathology 77:1495-1497. 1987.

LATERELL, F.M. \& ROSSI, A. Gray leaf spot of corn: A disease on the move. Plant Disease 67:842-847. 1983.

MUNFORD, J.D. \& NORTON, G.A. Economics of decision making in pest management. Annual Review of Entomology 29:157-174. 1984.

NUTTER, F.W. \& JENCO, J.H. Development of a criticalpoint yield loss model to estimate yield losses in corn caused by Cercospora zeae-maydis. Phytopathology 82:994. 1992. (Abstract)

REIS, E.M., CASA, R.T. \& BRESOLIN, A.C.R. Manual de Diagnose e Controle de Doenças de Milho. Lages SC. Graphel. 2004.

SAH, D.N. \& MacKENZIE, D.R. Methods of generating different levels of disease epidemics in loss experiments. In: Teng, P.S. (Ed.) Crop loss assessment and pest management. Saint Paul MN. APS Press. 1987. pp. 90-95.

VIÉGAS, A.P. Alguns fungos do Brasil. Bol. Soc. Bras. Agronomia, Rio de Janeiro 8:160. 1945.

WARD, J.M.J., STROMBERG, E.L., NOWELL, D.C. \& NUTTER, F.W. Gray leaf spot. A disease of global importance in maize production. Plant Disease 83:884-895. 1999.

Received 31 August 2005 - Accepted 29 March 2007 - FB 5083 